\title{
The management of acute visual failure
}

\author{
Shirley H Wray
}

Acute visual failure is the presenting symptom of an ocular stroke. Ocular strokes are due to a central retinal artery (CRA) occlusion, branch retinal artery (BRA) occlusion or anterior ischaemic optic neuropathy (AION) which is the result of infarction of the optic nerve.

\section{Central retinal artery occlusion} CLINICAL SIGNS AND SYMPTOMS

Sudden blindness is the major symptom in CRA occlusion unless a cilioretinal artery is present to supply circulation to the macula. Eye pain is atypical, but when present suggests involvement of the ophthalmic artery.

Blindness is confirmed by failure of the pupil to react to direct light, but what is seen ophthalmoscopically depends on how soon after the occlusion the examination is made. If the fundus is examined within the first few minutes whilst the occlusion persists, the striking finding is the presence of segmentation of the blood column, boxcar segmentation, with slow "streaming" of flow in the retinal veins. Blood in the arterial branches is dark and a few arterioles may show segmentation, (clear areas alternating with areas where the cells appear clumped together), but this is nowhere so obvious as in the veins.

Ophthalmoscopy is not often performed within the first hour, however, and later inspection of the fundus will show surprising-

Figure 1 Central retinal artery occlusion with opacification of the retina and a macula cherry-red spot. ly little. Typically the disc will show no more than mild pallor while the arteries may be only slightly attenuated. Gentle digital pressure on the globe during ophthalmoscopy may nevertheless elicit segmentation of the blood column, indicating the presence of a slow but not completely arrested circulation. Total obstruction posterior to the lamina should be suspected when the retinal arteries on the disc start to pulsate at a touch indicating very low retinal diastolic pressure. When the signs of CRA occlusion are secondary to an ophthalmic artery occlusion, the intraocular pressure in the eye is low.

With the passage of time, typically after an hour or more, the characteristic fundus changes are seen. The ischaemic retina takes on a white ground glass appearance and the normal red colour of the choroid showing through at the fovea accentuates the central cherry-red spot at the macula (fig 1). Within days of the acute event, the retinal opacification, the cherry-red spot and the nerve fibre layer disappear and optic atrophy of the primary type develops.

\section{PATHOGENESIS}

There are five principal causes of occlusion of the CRA: 1 Embolic obstruction; 2 Occlusion in situ in association with atheromatous disease when the narrowed arterial lumen becomes obliterated by superimposed thrombosis or haemorrhage; 3 Inflammatory endarteritis, such as temporal arteritis, ${ }^{1}$ thromboangiitis obliterans, ${ }^{2}$ and polyarteritis nodosa with involvement of the choroidal and retinal arteries; ${ }^{3} 4$ Simple angiospasm, a rare cause that may be the mechanism of CRA occlusion associated with Raynaud's disease ${ }^{4}$ or with migraine; 5 Arterial occlusion that occurs hydrostatically with either the high intraocular pressure of glaucoma; the low retinal blood pressure of carotid stenosis or the aortic arch syndrome; or severe hypotension.

The cause of the CRA occlusion may be evident if examination shows: a retinal embolus, hypertension, atrial fibrillation and/or disease of other arteries, notably the ophthalmic or temporal artery or the internal carotid artery in the neck. However, even in cases of embolic genesis, an embolus may not be seen because emboli frequently impact behind the lamina cribosa. 
Table 1 Types of amaurosis fugax.

\begin{tabular}{|c|c|c|c|c|}
\hline & Type I & Type II & Type III & Type IV \\
\hline $\begin{array}{l}\text { Onset } \\
\text { Visual loss }\end{array}$ & $\begin{array}{l}\text { Abrupt } \\
\text { All or } \\
\text { partial }\end{array}$ & $\begin{array}{l}\text { Less rapid } \\
\text { All or } \\
\text { partial }\end{array}$ & $\begin{array}{l}\text { Abrupt } \\
\text { Total or } \\
\text { progressive } \\
\text { contraction of } \\
\text { visual fields }\end{array}$ & $\begin{array}{l}\text { Abrupt } \\
\text { Resembles Type } \\
\text { I or II }\end{array}$ \\
\hline Length & $\begin{array}{l}\text { Seconds or } \\
\text { minutes }\end{array}$ & $\begin{array}{l}\text { Minutes or } \\
\text { hours }\end{array}$ & Minutes & Any length \\
\hline Recovery & Complete & Complete & $\begin{array}{l}\text { Usually } \\
\text { complete }\end{array}$ & Complete \\
\hline $\begin{array}{l}\text { Pain } \\
\text { Mechanism }\end{array}$ & $\begin{array}{l}\text { No } \\
\text { Embolus } \\
\text { Arteritis }\end{array}$ & $\begin{array}{l}\text { Rare } \\
\text { Hypoperfused } \\
\text { carotid/ } \\
\text { ophthalmic } \\
\text { occlusive } \\
\text { disease }\end{array}$ & $\begin{array}{l}\text { Often } \\
\text { Vasospasm } \\
\text { (migraine) } \\
\text { ophthalmic } \\
\text { artery or } \\
\text { central } \\
\text { retinal artery }\end{array}$ & $\begin{array}{l}\text { No } \\
\text { Anticardiolipid } \\
\text { antibodies or } \\
\text { Idiopathic }\end{array}$ \\
\hline $\begin{array}{l}\text { Unusual } \\
\text { Features }\end{array}$ & $\begin{array}{l}\text { Vision may } \\
\text { black out } \\
\text { completely }\end{array}$ & $\begin{array}{l}\text { Loss of contrast } \\
\text { vision. } \\
\text { Photopsias. } \\
\text { Sunlight } \\
\text { provoked }\end{array}$ & $\begin{array}{l}\text { Visual loss } \\
\text { may spare } \\
\text { fixation }\end{array}$ & $\begin{array}{l}\text { Alternating } \\
\text { between } \\
\text { eyes }\end{array}$ \\
\hline
\end{tabular}

*Based on 850 personal cases, ${ }^{\circ}$ Wray SH. Extracranial internal carotid artery disease. In Bernstein EF, ed. Amaurosis fugax. New York, Springer-Verlag, 1988: 72-800.

Transient monocular blindness (Type I or II, see table 1) as a premonitory symptom of CRA occlusion suggests an embolic cause or temporal arteritis. ${ }^{6}$ In patients under the age of 40 , the heart is the leading source of emboli $^{78}$ due to rheumatic valvular disease, bacterial endocarditis, or cardiac myxoma (table 2). ${ }^{9}$ In older patients, the source of the embolus may be cardiac $^{10}$ or intra-arterial from atheromatous ulceration of the aorta or the ipsilateral internal carotid artery.

Trauma is also an important cause of CRA occlusion. Compression of the globe may be self-inflicted in circumstances involving heavy alcohol use and/or drug consumption followed by stupor. ${ }^{11}$ Iatrogenic CRA occlusion has been reported in patients undergoing surgery where prolonged pressure to the orbit has occurred inadvertently in association with a period of hypotension during anaesthesia. ${ }^{12} 13$

DIAGNOSIS

The diagnosis of CRA occlusion is usually straightforward. However, the differential diagnosis of acute persistent monocular visual

Table 2 Sources of emboli

\begin{tabular}{|c|c|c|}
\hline & Type & Patient age \\
\hline \multicolumn{3}{|l|}{ Cardiac } \\
\hline Rheumatic disease & Platelet/Calcium * & Any age \\
\hline Lupus & Platelet & Young women \\
\hline $\begin{array}{l}\text { Acute or subacute } \\
\text { endocarditis }\end{array}$ & Marasmic & $\begin{array}{l}\text { Damaged } \\
\text { heart }\end{array}$ \\
\hline Floppy mitral valve & Platelet & $\begin{array}{l}\text { Any age; } \\
\text { mostly women }\end{array}$ \\
\hline \multicolumn{3}{|l|}{ Chamber } \\
\hline Myxoma & Myxoma & \\
\hline Mural thrombus & Platelet/clot & Older adult \\
\hline Carotid artery & & \\
\hline Ulcerated plaque & $\begin{array}{l}\text { Platelet/cholesterol } \\
\text { ester }\end{array}$ & Older adult \\
\hline Stenosis & Platelet & \\
\hline Fibromuscular dysplasia & Platelet & Young woman \\
\hline $\begin{array}{l}\text { Other } \\
\text { Amniotic }\end{array}$ & Debris?* & Young woman \\
\hline Long bone fractures & $\mathrm{Fat}^{\star}$ & Any age \\
\hline Chronic iv drug users & Talc ${ }^{\star}$ & Any age \\
\hline $\begin{array}{l}\text { Disseminated intravascular } \\
\text { coagulopathy }{ }^{\star}\end{array}$ & $? ?$ & ?? \\
\hline $\begin{array}{l}\text { Antiphospholipid } \\
\text { antibody(s) }\end{array}$ & ?? & Young adult \\
\hline
\end{tabular}

«Produces retinal infarction; no amaurosis fugax. Reproduced with modification, courtesy of Burde $\mathrm{RM}^{\circ}$ Amaurosis fugax, an overview. $\mathcal{f}$ Clin Neuro-ophthal 1989;9(3):185-189. failure includes a number of ophthalmic emergencies, that is, AION, acute occlusion of the central retinal vein, detachment of the macula, acute closed-angle glaucoma, sudden vitreous or macular haemorrhage, as well as factitious visual loss.

\section{MANAGEMENT}

Bock et al $^{14}$ and Hayreh et al ${ }^{15}$ suggest that the retina suffers irreparable damage after a CRA occlusion of 105 minutes but may recover well within 97 minutes of the ictus. However, by the time most CRA occlusions are seen, there is usually a longer lapse of time and there is no effective treatment available for the restoration of normal vision. Nonetheless, every case deserves referral for urgent treatment since restoration of an area of peripheral visual field may be achieved.

The initial treatment consists of laying the patient flat and giving firm ocular massage to lower intraocular pressure and help dislodge the embolus into the peripheral retinal circulation. ${ }^{16}$ The patient should rebreathe into a paper bag to build up carbon dioxide and receive $500 \mathrm{mg}$ of intravenous Diamox.

Immediately after the initial therapy, when fundoscopy shows boxcar segmentation in the retinal arterioles, the patient should be referred on an urgent basis to an ophthalmologist for an anterior paracentesis. In the absence of a cherry-red spot and boxcarring in the retinal arterioles, the patient should be referred to a retina specialist for an urgent timed fundus fluorescein angiogram to determine the site of the arterial block. The fundus fluorescein angiogram in a CRA occlusion will show a normal arm to eye circulation time and choroidal phase and a delay in filling of the branches of the central retinal artery. The fundus fluorescein angiogram in an ophthalmic artery occlusion will show a delayed arm to eye circulation time and simultaneous delayed flow in both the choroidal and retinal (CRA) circulation.

In CRA occlusion, in the late stage, where a cherry-red spot is present, an anterior paracentesis may be of little benefit because the infarcted retina is probably already damaged beyond recovery. ${ }^{17}$ Nevertheless, in eyes that have been blind for several hours heroic measures can be undertaken even if 24 hours have elapsed since gratifying recovery of vision has been reported in eyes treated 6,8 and 12 hours after the event. ${ }^{18}$

Heparin anticoagulation is useful in the treatment of an impending CRA occlusion. High dose systemic corticosteroids are essential in the therapy of suspected inflammatory arteritis.

Management of patients with central retinal artery occlusion must also include an evaluation for associated hypertension, cardiac disorders, arterial vascular disease, (ophthalmic, temporal and ICA), and the presence of antiphospholipid antibodies.

Hypertension is an important factor in the genesis of all strokes. The early detection of hypertension, its vigorous treatment and close surveillance may be expected to reduce the 
increasing prevalence of CRA occlusion. Heart disease is frequently present in patients with CRA occlusion. In a retrospective study of patients with CRA occlusion, Appen et al ${ }^{8}$ found that $30 \%$ of younger and $23 \%$ of older patients had associated cardiac valvular disease. In a prospective study, ${ }^{19} 56 \%$ of patients under the age of fifty had a potential cardiac source of embolus, compared with $24 \%$ in the older age group. Aortic stenosis was the most frequent lesion but mitral leaflet prolapse was an isolated finding in ten patients. The data emphasise the vital importance of careful cardiac assessment, especially in young patients.

Ophthalmic artery occlusion mimics a CRA occlusion clinically and produces opacification of the infarcted retina. But, the typical cherry-red spot may be absent or extremely indistinct due to coexisting infarction of the choroid. Optic atrophy and retinal pigment epithelial changes develop subsequently and are present funduscopically. ${ }^{20-22}$ A timed fundus fluorescein angiogram is the test of choice to diagnose ophthalmic artery occlusion. The flash electroretinogram is also valuable and shows absence of both the aand $b$ - waves. ${ }^{23}$ Ophthalmic artery occlusion carries a very poor prognosis for vision, ${ }^{21}$ in two isolated cases, however, vision recovered from light perception vision to $20 / 30^{22}$ and from an acuity of counting fingers at 6 inches to 20/50 with the restoration of normal retinal and choroidal blood flow.

An occlusion of the CRA may be the only symptom of giant cell arteritis in $5-10 \%$ of elderly patients and the risk of blindness in the fellow eye is extremely high. Diagnostically, giant cell arteritis is characterised by an elevation of the erythrocyte sedimentation rate (ESR) and the fibrinogen level, and an inflammatory arteritis with giant cells on histopathological examination of an affected artery. However, a high index of suspicion clinically, with or without an abnormal ESR and fibrinogen level is an indication for immediate high dose corticosteroid therapy (prednisone $80 \mathrm{mg}$ daily until ESR starts to fall, tapering to $15 \mathrm{mg}$ daily as soon as ESR is normal) pending a temporal artery biopsy.

Ipsilateral internal carotid artery stenosis and/or ulceration may be the cause of a CRA occlusion and auscultation of the neck, eyes and head for a bruit is important. Quantitative phonoangiography is useful in the evaluation of a carotid bruit. The residual lumen diameter at the point of stenosis can be accurately estimated in about $90 \%$ of patients. Other carotid non-invasive tests help to determine if there is a haemodynamically significant lesion. Periorbital Doppler ultrasonography reveals the direction of flow in external carotid branches on the brow. Reversal of flow indicates reduced pressure in the internal carotid artery system. Oculoplethysmography measures the relative arrival time of the ocular pulse in each eye. A delay of greater than $20 \mathrm{~ms}$ is significant. This is the most useful test for studying the deep orbital circulation. B-scan ultrasonography is also valuable to construct a real-time tomographic image of the carotid bifurcation. Patients with significant medical risk factors can also be studied non-invasively with magnetic resonance angiography (MRA) of the neck and brain. Candidates for carotid endarterectomy require carotid angiography.

In one study ${ }^{24}$ significant internal carotid artery disease was found by carotid angiography in nine of nine patients who had a CRA occlusion. Three patients had complete occlusion of the internal carotid artery on the same side, 4 had significant stenosis, and 3 had evidence of an ulcerated plaque.

In a second report of 62 patients with CRA occlusion $^{25} 25$ patients had carotid angiography and $56 \%$ of these had ipsilateral extracranial internal carotid artery disease. Somewhat surprisingly these patients generally did not have carotid bruits and had normal findings on non-invasive carotid tests. Ten of $14 \mathrm{had}$ ipsilateral carotid endarterectomy and were found to have either an embologenic ulcerated plaque or tight ICA stenosis. In this study 11 of 62 patients had normal angiograms and 13 who did not have angiography had clinical evidence of other "etiologic" factors. The remaining 24 patients had no diagnostic work up.

Occlusion of the CRA in association with a complete occlusion of the ipsilateral internal carotid artery may be due to propagation of thrombus from the carotid siphon into the ophthalmic artery. ${ }^{26}$ Combined data ${ }^{542728}$ suggest that if no cause is apparent clinically for the retinal stroke, and no alternative cause is evident, it is likely that the ipsilateral carotid artery is occluded or stenosed or ulcerated and that one patient in seven will go on to have a stroke.

CRA occlusion has also been shown to be associated with elevated levels of antiphospholipid antibodies (anti-cardiolipin antibody, and lupus anti-coagulant (LA)). ${ }^{29-32}$ Clotting studies [prothrombin time (PT), partial thromboplastin time (PTT), and platelet count], and tests for systemic lupus erythematosus including antiphospholipid antibodies are indicated in young adults, especially women with CRA occlusion and retinal vascular disease. ${ }^{33} 34$

\section{PROGNOSIS}

The prognosis for visual recovery in CRA occlusion is extremely poor. Fifty eight per cent of eyes are blind, only $21 \%$ of eyes retain useful vision.

\section{Branch retinal artery occlusion}

CLINICAL SIGNS AND SYMPTOMS

The lodging of a calcific embolus in a branch of the CRA, usually at a first or second order bifurcation, produces sudden and permanent loss of a sector of the visual field with retinal infarction corresponding to the vascular territory of the arteriole (fig 2). Transient cerebral ischaemic attacks or a stroke are rare preceding symptoms in patients with branch retinal artery (BRA) occlusion unless large numbers 


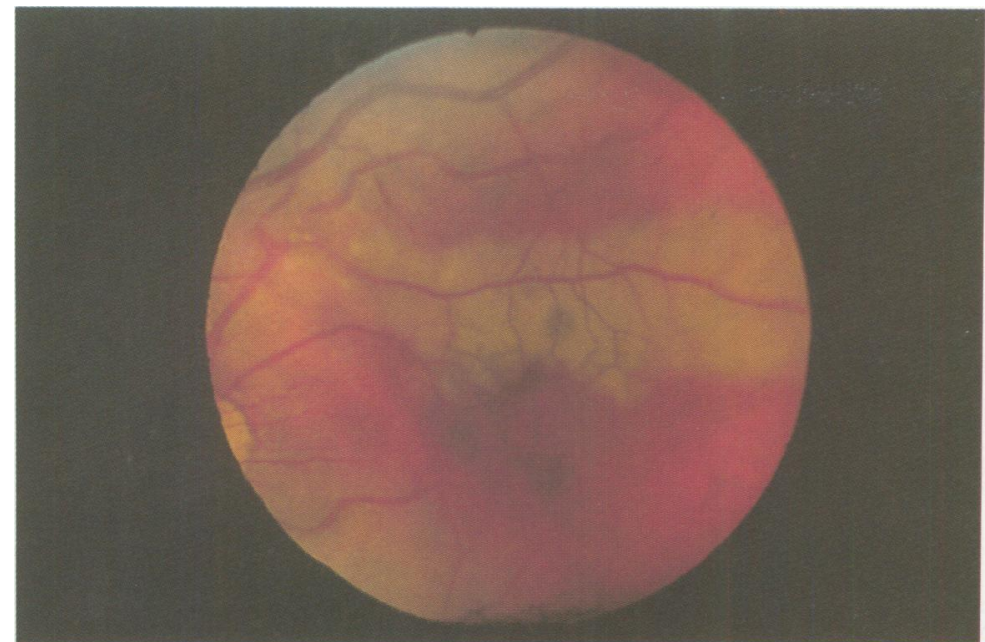

Figure 2 Branch retinal artery occlusion with impaction of two emboli in the artery. The retina shows an arcuate band of infarction.

of calcific emboli are released at the time of aortic or mitral valve surgery. Amaurosis fugax is the most common preceding visual symptom (table 3 ).

\section{PATHOGENESIS}

The ophthalmoscopic appearance of a retinal embolus can provide specific information about the embolic material and its possible source (table 2). Bright yellowish glinting lipid emboli (Hollenhorst plaques) are the most common emboli seen in the eye (fig 2). They have been confirmed to be cholesterol and they are associated with atheromatous changes of the ipsilateral carotid artery or aortic arch disease. ${ }^{35} 36$ Calcific emboli, in contrast, are characteristically matt-white, non-scintillating and somewhat wider than the blood column. Calcific emboli may be dislodged by the surgical manipulation of calcified heart valves at the time of valvulotomy or may occur spontaneously from rheumatic valvular vegetation. Some of the circulating microemboli that pass through the retina, socalled migrant pale emboli, are believed to be composed of platelets and their occurrence is associated with thrombocytosis. The emboli that occur after myocardial infarction fall into the category of fibrin plugs. They are especially frequent in patients who have neurological complications after open heart surgery.

Potential sources of emboli are: mitralannulus calcification causing cerebral and retinal emboli in the elderly, ${ }^{37-39}$ and a prolapsed mitral valve causing similar problems in younger patients. ${ }^{40-42}$ In the case of embolic seeding from a myxoma of the heart, the embolus shares the histopathology of the original tumour. ${ }^{7}$

\section{DIAGNOSIS}

A patient with a visible retinal embolus, even though suffering no visual loss, should be investigated urgently because of the risk of a stroke. Each case warrants a general physical examination with emphasis on the cardiovascular and neurovascular systems. At the Mayo Clinic, ${ }^{43}$ investigation includes oculopneumoplethysmography, carotid ultrasonography and Doppler studies, and blood tests to search for risk factors. If the patient is a candidate for endarterectomy, magnetic resonance angiography of the neck and brain and/or carotid angiography are advisable.

In patients with retinal emboli, especially calcific emboli, the investigative work up should focus on the heart valves. (table 4) Two-dimensional echo studies may reveal thickened, calcified valve leaflets or a tight calcified annulus.

\section{MANAGEMENT}

The management of an embolic BRA occlusion is dictated by the patient's vascular status. A carotid endarterectomy is the treatment of choice in a patient with a highgrade carotid artery stenosis and/or severe atheromatous ulceration. Anticoagulation with coumadin or aspirin is a conservative alternative for carotid occlusion without significant stenosis or ulceration.

Surgical treatment of a cardiac source of emboli, that is, aortic and/or mitral valve disease, is only warranted if the patient also has significant cardiac symptoms. Subsequent retinal embolisation from another calcific embolus is rare and a patient with an isolated calcific retinal embolus can usually be followed without treatment. Anticoagulation is advisable, however, in patients with atrial fibrillation. No treatment is recommended in patients with idiopathic emboli and a normal cardiac rhythm.

\section{PROGNOSIS}

Savino et al ${ }^{28}$ reported that patients with retinal infarcts and visible emboli showed a shortened survival compared to age- and sexmatched controls, $(59 \%$ versus $75 \%$, over
Table 3 Preceding vascular events in occlusion of branch and central retinal arteries *

\begin{tabular}{lll}
\hline & \multicolumn{2}{l}{ Retinal artery occlusion } \\
\cline { 2 - 3 } Preceding event & $\begin{array}{l}\text { Branch } \\
n=68\end{array}$ & $\begin{array}{l}\text { Central } \\
n=3 *\end{array}$ \\
\hline Amaurosis fugax & $12(18)$ & $4(11)$ \\
Transient cerebral ischaemia & $8(12)$ & $1(3)$ \\
Stroke & $2(3)$ & $4(11)$ \\
Ischaemic heart disease & $15(22)$ & $2(6)$ \\
Claudication & $5(7)$ & $2(6)$ \\
\hline
\end{tabular}

*Based on data in ref. $19 .{ }^{\star \star} 43$ male, 25 female patient mean age 55 . Numbers in parentheses are percentages. $\star \star \star 23$ male, 12 female patients; mean age 36 .
Table 4 Clinical findings in occlusion of branch and central retinal arteries *

\begin{tabular}{lll}
\hline & \multicolumn{2}{l}{ Retinal artery occlusion } \\
\cline { 2 - 3 } Clinical finding & $\begin{array}{l}\text { Branch } \\
n=68\end{array}$ & $\begin{array}{l}\text { Central } \\
n=35\end{array}$ \\
\hline Hypertension & $17(25)^{\star \star}$ & $20(57)$ \\
Carotid bruit & $12(18)$ & $5(14)$ \\
Visible retinal embolus & $46(68)$ & $4(11)$ \\
Cardiac valvular abnormality & $23(34)$ & $6(17)$ \\
\hline *Based on data in ref. 19 & & \\
$\star \star$ Numbers in brackets are percentages.
\end{tabular}


Figure 3 Diagrammatic representation of the locations of the watershed zone (arrows and shaded areas) between the medial and lateral posterior ciliary arteries in human eyes. In the upper left illustration, the shaded area represents the location where the watershed zone may be situated anywhere within this area. The remaining five illustrations are examples of the variations in the location. (From reference 45, with

permission.)

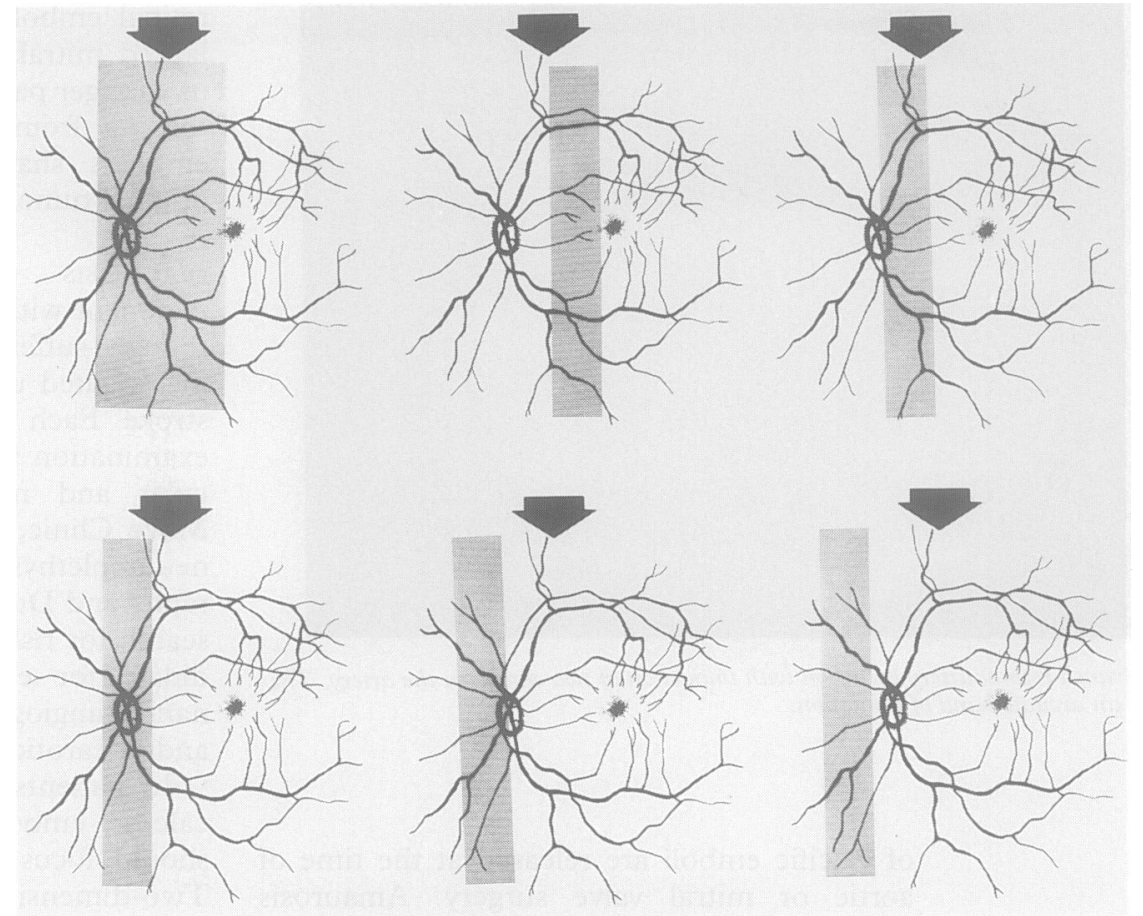

nine years) and that a visible retinal embolus predicted a dramatic reduction in survival $(44 \%)$. When no embolus was visible, more patients survived. Death was related in most cases to cardiac infarction.

\section{Anterior ischaemic optic neuropathy}

Anterior ischaemic optic neuropathy due to acute infarction of the optic nerve head is a common cause of sudden persistent visual failure in patients past middle age. ${ }^{44}$

The blood supply of the optic nerve head is primarily derived from choroidal and posterior ciliary branches of the ophthalmic artery. The posterior ciliary arteries arise from the ophthalmic artery as independent branches, or in common with other branches of the ophthalmic artery and may number two (in $48 \%$ ), three (in $39 \%$ ) or four branches (in $8 \%)$. There are usually only two posterior ciliary arteries, a medial posterior ciliary artery and a lateral posterior ciliary artery. These vessels are end arteries, so that the border zone between the areas of the supply of the medial PCA and the area of supply of the lateral PCA is a watershed zone. The lateral and

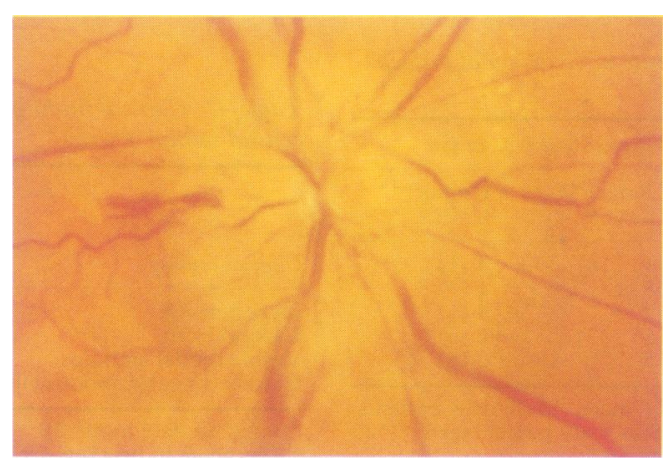

medial PCAs supply the corresponding half of the choroid. In humans the watershed zone may be located anywhere between the fovea and the nasal border of the optic disc (fig 3). ${ }^{45}$ The position of the watershed zone is of great clinical significance because it determines the extent of involvement of the optic nerve head by ischaemia following an occlusion of one of the two main posterior ciliary arteries. ${ }^{45} 46-48$

\section{CLINICAL SIGNS AND SYMPTOMS}

Anterior ischaemic optic neuropathy occurs most often in patients over the age of 40 . Typically, sudden, painless visual field loss, an altitudinal field defect, and pallor and swelling of the optic disc occur. Rarely, optic disc changes precede visual loss. Occasionally, visual loss may progress over 1-7 days.

The ischaemic optic disc has a characteristic appearance on funduscopic examination. Usually there is no significant hyperaemia, and even in the early stages the disc tends to be pale. Both the swelling and the pallor may be sectorial, affecting only the superior or inferior half of the disc head. Superficial flame shaped haemorrhages are frequently present, mainly along the peripapillary capillaries (fig 4). When the disc oedema begins to subside, optic atrophy develops and optic disc cupping, similar to that seen in glaucoma, may occur.

In rare cases, embolic ischaemic optic neuropathy can be diagnosed funduscopically by the presence of ischaemic disc swelling and emboli in the branches of the CRA.

\section{PATHOGENESIS}

Anterior ischaemic optic neuropathy (AION) occurs in two forms: 1) non-arteritic (median age fifty six years) in which the risk factors are diabetes mellitus in younger patients and 
hypertension in older patients; ${ }^{49-53}$ and 2) An arteritic variety due to giant cell arteritis (median age seventy-four years). Symptoms of giant cell arteritis, anorexia, malaise, proximal arthralgia, myalgia, headache, jaw claudication and an elevated ESR and/or fibrinogen level, are indications for prompt systemic corticosteroid therapy and a temporal artery biopsy. Arteritic ischaemic optic neuropathy may affect the contralateral eye and cause blindness in $40 \%$ of cases.

Systemic conditions in association with non-arteritic AION include collagen vascular diseases, such as systemic lupus erythematosis and polyarteritis nodosa, arterial hypotension during surgical procedures, renal haemodialysis or massive haemorrhage and haematological disorders such as sickle-cell trait, polycythaemia, thrombocytopenic purpura, leukaemia and various types of anaemia. Ocular factors include no cup or only a small cup in the optic disc, ${ }^{53} 54$ raised intraocular pressure and marked optic disc oedema. In non-arteritic AION about $50 \%$ of cases develop second eye involvement after an interval that can range from months to years.

Embolism has not been thought to be a major factor in the pathogenesis of AION until relatively recently. Eagling et a $\bar{F}^{5}$ studied forty patients ( 56 eyes) with AION and found only two patients with retinal emboli. Liberman et $a \bar{F}^{6}$ published one of the early reports demonstrating multiple emboli occluding small-vessels that had led to retrolamina infarction of the optic nerve. Burde et $a l^{20}$ described a patient with metastatic chondrosarcoma with clinical findings of AION and compromised retinal blood flow. Histological sections of the eye revealed emboli in the short posterior ciliary arteries as well as in the choroidal vessels and CRA. Portnoy et $a{ }^{57}$ described a man with cholesterol emboli within the retinal vasculature combined with a clinical picture of AION and choroidal non-perfusion demonstrated by FFA. In this patient the source of the multiple emboli was an ulcerating plaque in the ipsilateral left carotid artery. I have seen three cases of AION combined with retinal and posterior ciliary artery emboli, post coronary artery bypass surgery. Choroidal infarction was detected in each case by fluorescein angiography. ${ }^{58}$

\section{DIAGNOSIS}

The diagnosis of AION is based on the presence of an altitudinal or complex nerve fibre bundle field defect, ischaemic swelling of the optic disc and peripapillary haemorrhages. In nonapoplectic AION with progressive visual loss, compression of the nerve by a mass lesion must be ruled out by a gadolinium MRI of the optic nerve and chiasm.

\section{MANAGEMENT}

Diagnostic studies are urgently required in all cases of AION. They include a complete blood count, ESR, fibrinogen level, ausculation of the heart, neck, eyes and head and carotid noninvasive studies, including transorbital Doppler. A temporal artery biopsy is indicated when there is a high index of clinical suspicion of temporal arteritis. A cardiac work up and MRA of the neck and brain are indicated when AION is thought to be embolic. In non-arteritic AION, tests should also be directed towards the detection of hypertension, diabetes mellitus and hyperlipidemia.

Urgent high dose corticosteroids pending a temporal artery biopsy are the treatment of choice in arteritic AION. Embolic AION, when symptomatic of ipsilateral carotid atheroma should be managed according to the severity of the carotid disease.

Unfortunately, there is no effective treatment for non-arteritic AION. The use of optic nerve sheath decompression for treatment of progressive non-arteritic AION is highly controversial, 5960 and corticosteroids are of questionable value, although they are frequently used when the second eye becomes involved.

\section{PROGNOSIS}

The prognosis for recovery of vision in AION is poor, particularly in patients with the arteritic variety due to giant cell arteritis.

The long term clinical course of patients with AION is not well documented. In one follow up study of 205 patients with nonarteritic AION there was a slightly greater incidence of stroke and myocardial infarction than expected but no greater mortality.$^{61}$ In a retrospective study of 71 patients with nonarteritic AION the data showed a 2-3 fold higher myocardial and cerebral infarction mortality than expected. ${ }^{62}$

\section{Summary}

This review of acute visual failure covers the clinical manifestations and management of ocular strokes CRA occlusion, BRA occlusion and AION.

The diagnostic process for each patient requires meticulous attention to:

1 Blood pressure, heart rate and rhythm, palpation of the temporal arteries, and auscultation of the heart, neck, eyes and head.

2 Dilated funduscopic examination.

3 Immediate blood tests: complete blood count, PT, PTT, platelet count, ESR, fibrinogen level, fasting blood sugar, cholesterol, triglyceride and blood lipids. A test for antiphospholipid antibodies (ACLA and LA) is recommended in unexplained cases of CRA occlusion.

Non-invasive investigations should utilise a battery of tests:

1 Carotid non-invasive studies; the useful tests give information about the presence of a haemodynamic lesion (Dopper ultrasonography and oculoplethysmography), analyse the bruit to determine the residual lumen diameter (phonoangiography), or image the artery with ultrasound (B-Scan ultrasonography).

2 Two-dimensional echocardiogram

Invasive investigations are required in selected patients: 
1 A temporal artery biopsy

2 A carotid arteriogram if the patient is a candidate for endarterectomy. The patient can be screened first with a non-invasive MRA of the neck and brain.

3 A timed FFA, particularly in cases of CRA occlusion when occlusion of the ophthalmic artery is suspected, in cases of AION of possible embolic origin or in AION to document the position of the watershed zone of the choroidal circulation and its relation to the optic nerve head.

Emergency treatment in CRA occlusion is designed to lower intra-ocular pressure and dislodge the embolus. In impending CRA occlusion heparin is useful. Urgent systemic corticosteroids are needed when CRA occlusion, or AION are due to arteritis. In other situations treatment is directed towards preventing recurrence or involvement of the other eye by reducing or eliminating identified risk factors.

1 Cullen JF. Occult temporal arteritis. Trans Ophthal Soc UK 1963;83:725.

2 Gresser EB. Partial occlusion of retinal vessels in a case of thromboangitis obliterans. Am f Ophthal 1932;15:235.

3 Goldsmith J. Periarteritis nodosa with involvement of the choroidal and retinal arteries. Am $\mathcal{F}$ Ophthal 1946; 29:435.

4 Anderson RG and Gray EB Spasm of the central retinal artery in Raynaud's disease. Arch Ophthal 1937;17:662.

5 Katz B. Migrainous central retinal artery occlusion. $f$ Clin Neuro-Ophthal 1986;6:69-75.

6 Wray SH. Extracranial internal carotid artery disease. In: Bernstein EF, ed. Amaurosis Fugax. New York: Springer-Verlag, 1988:72-800.

7 Cogan DG, Wray SH. Vascular occlusions in the eye from cardiac myxomas. Am f Ophthal 1975;80:396-403.

8 Appen RE, Wray SH and Cogan DG. Central retinal artery occlusion. Am $\mathcal{f}$ Ophthal 1975;79:374.

9 Burde RM. Amaurosis fugax, an overview. I Clin Neuroophthal 1989;9(3):185-9.

10 Zimmerman LE. Embolism of central retinal artery; secondary to myocardial infarction with mural thrombosis. Arch Ophthal 1965;73:822.

11 Jayam AV, Hass WK, Carr RE and Kumar AJ. Saturday night retinopathy. F Neurolog Sci 1974;22:413.

12 Givner I, Jaffe N. Occlusion of the central retinal artery following anesthesia. Arch Ophthal 1950;43:197.

13 Hollenhorst RW, Svien HJ and Benoit CF. Unilateral blindness occurring during anesthesia for neurosurgical operation. Arch Ophthal 1954;52:819.

14 Bock J, Bornschein $\mathrm{H}$, Hommer $\mathrm{K}$. The recuperative time of the human retina. An electroretinographic study. Albrecht von Graefes. Arch Klin Exp Ophthal 1963;165: 437-51.

15 Hayreh SS, Kolder HE, Weingeist TA: Central retinal artery occlusion and retinal tolerance time. artery occlusion and re

16 Sfytche TJ, Bulpitt CJ, Kohner EM, et al. Effect of changes in intraocular pressure on the retinal microcirchanges in intraocular pressure on the
culation. Br 7 Ophthal $1974 ; 58: 514-22$.

17 Magargal LE, Goldberg RE. Anterior chamber paracentesis in the management of acute nonarteritic central retinal artery occlusion. Surg Forum 1977;28:518-21.

18 Stone R, Zink H, Klingele T, Burde RM. Visual recovery after central retinal artery occlusion: Two cases. Annals Ophthal 1977;9:445.

19 Wilson IA, Warlow CP, Ross Russell RW. Cardiovascular disease in patients with retinal arterial occlusion. Lancet 1979;1:1292-294.

20 Burde RM, Smith ME, Black JT. Retinal artery occlusion in the absence of a cherry red spot. Surv of Ophthal 1982;27:(3) 181-6.

21 Brown GC, Magargal LE, Sergott R. Acute obstruction of the retinal and choroidal circulations. Ophthalmology 1986;93:1373-82.

22 Duker JS, Brown GC. Recovery following acute obstruction of the retinal and choroidal circulations. Retina 1988;8:257-60.

23 Henkes HE. Electroretinography in circulatory disturbances of the retina. II. The electroretinogram in cases of occlusion of the central retinal artery or of one of its branches. Arch Ophthal 1954;51:42.

24 Kollarits CR, Lubow M, Hissong SL. Retinal strokes. I. Incidence of carotid atheromata. $¥ A M A$ 1972;222:1273.

25 Sheng FC, Quinones-Baldrich W, Machleder HI, et al. Relationship of extracranial carotid occlusion disease and central retinal artery occlusion. Am $₹$ Surg 1986; 152:175-8.

26 Ross Russell RW. Observations on the retinal blood vessels in monocular blindness. Lancet 1961;2:1422-8.
27 Kearns TP, Hollenhorst RW. Venous stasis retinopathy of occlusive disease of the carotid artery. Mayo Clin Proc 1963;38:304-12.

28 Savino PJ, Glaser JS, Cassady J. Retinal Stroke: Is the patient at risk. Arch Ophthal 1977;95:1185-9.

29 Englert H, Hawkes CH, Boey ML, et al. Dego's disease Association with anticardiolipin antibodies and the lupus anticoagulant. $B M \mathcal{F}$ 1984;289:576.

30 Glueck HI, Kant KS, Weiss MA, et al. Thrombosis in systemic lupus erythematosus: relation to the presence of circulatory anticoagulants. Arch Intern Med 1985;145: 1389-95.

31 Shalev Y, Green L, Pollack A, et al. Myocardial infarction with central retinal artery occlusion in a patient with antinuclear antibody-negative systemic lupus erythematosus. Arthritis Rheum 1985;28:1185-7.

32 Jonas J, Kolbe K, Volcker HE, et al. Central retinal artery occlusion in Sneddon's disease: association with antiphospholipid antibodies. Am $\mathcal{f}$ Ophthal 1986;102 37-40.

33 Pulido JS, Ward LM, Fishman GA, et al. Antiphospholipid antibodies associated with retinal vascular disease. Retina 1987;7:215-18.

34 Silverman M, Lubeck MJ, Briney WG. Central retinal vein occlusion complicating systemic lupus erythematosus. Arthritis Rheum 1978;21:839-43.

35 Hollenhorst RW. The ocular manifestations of internal carotidarterial thrombosis. Med Clin North Am 1960;4: 897-908.

36 Hollenhorst RW. Significance of bright plaques in the retinal arterioles. $\mathcal{F} A M A$ 1961;178:123-29.

37 D'Cruz IA, Cohen HC, Prabhu R, et al. Clinical manifestations of mitral-annulus calcification, with emphasis on its echocardiographic features. Am Heart $\mathcal{f}$ 1977;94: $367-7$

38 Guthrie J, Fairgrieve J. Aortic embolism due to myxoid tumor associated with myocardial calcification. $\mathrm{Br}$ Hear f 1963;25:137-140.

39 diBono DP, Warlow CP. Mitral-annulus calcification and cerebral or retinal ischemia. Lancet 1979;2:383-5.

40 Barnett HJM. Transient cerebral ischemia pathogenesis, prognosis and manageme

. occlusion of major cerebral arteries. Neurology 1978;28: occlusion

42 Barnett HJM., Boughner DR, Wayne Taylor D, et al. Further evidence relating mitral valve prolapse to cerebral ischemic events. $N$ Engl f Med 1980;302:139-44.

43 Younge BR. The significance of retinal emboli. $f$ Clin Neuro-ophthal 1989;9(3):190-94.

44 Boghen DR, Glaser JS. Ischemic optic neuropathy. The clinical profile and natural history. Brain 1975;98 689-708.

45 Hayreh SS. Arterial blood supply of the eye in Amaurosis Fugax. In: Bernstein EF, ed. New York: SpringerVerlag, 1988:1-23.

46 Hayreh SS. Anterior ischemic optic neuropathy. Berlin Springer-Verlag, 1975:3-23.

47 Hayreh SS. Anterior ischemic optic neuropathy. I Terminology and pathogenesis. Br $\mathcal{F}$ Ophthal 1974;58: Termino 63 .

48 Hayreh SS. Anterior ischaemic optic neuropathy. II. Fundus on ophthalmoscopy and fluorescein angiography. Br f Ophthal manifestations 1974;58:964-80.

49 Ellenberger C Jr, Keltner JL, Burde RM. Acute optic neuropathy in older patients. Arch Neurol 1973;28:182-5.

50 Repka MX, Savino PJ, Schatz NJ, Sergott RC. Clinical profile and long-term implications of anterior ischemic optic neuropathy. Am $\mathcal{f}$ Ophthal 1983;96:478-83.

51 Beri M, Klugman MR, Kohler JA, Hayreh SS. Anterior ischemic optic neuropathy. VII. Incidence of bilaterality and various influence factors. Ophthalmology 1987;94: 1020-8.

52 Ellenberger $\mathrm{C} \mathrm{Jr}$. Ischemic optic neuropathy as a possible early complication of vascular hypertension. $\mathrm{Am} f$ Ophthal 1979;88:1045-51.

53 Beck RW, Savino PJ, Repka MX, Schatz NJ, Sergott RC. Optic disc structure in anterior ischemic optic neuropaOptic disc structure in anterior isch
thy. Ophthalmology 1984;91:1334-6.

54 Doro S, Lessell S. Cup-disc ratio and ischemic optic neuropathy. Arch Ophthal 1985;103:1143-4.

55 Eagling EM, Sanders MD, Miller SJH. Ischemic papillopathy. Clinical and fluorescein angiographic review of lopathy. Clinical and fluorescein angiograph
forty cases. $B r f$ Ophthal 1974;58:990-1008.

56 Lieberman MF, Shahi A, Green WR. Embolic ischemic optic neuropathy. Am f̧Ophthal 1978;86:206-10.

57 Portnoy SL, Beer PM, Packer AJ, et al. Embolic anterio ischemic optic neuropathy. $\mathcal{F}$ Clinic Neuro-ophthal 1989; 9(1):21-25.

58 Wray SH. Embolic anterior ischemic optic neuropathy and branch retinal artery embolic occlusion post coronary artery by-pass surgery, (unpublished data) 1989

59 Sergott RC, Cohen MS, Bosley TM, Savino PJ. Optic nerve decompression may improve the progressive form of nonarteritic ischemic optic neuropathy. Arch Ophthalmol 1989;107:1743-54.

60 Letter to Editor. Arch Ophthalmol 1990;108:1063-68.

61 Guyer DR, Miller NR, Auer CL, et al. The risk of cerebrovascular and cardiovascular disease in patients with anterior ischemic optic neuropathy. Arch Ophthalmol 1985;103:1136-42.

62 Sawle GV, James CB, Ross-Russell RW. The natural history of non-arteritic anterior ischaemic optic neuropathy. $\mathcal{f}$ Neurol Neurosurg Psychiatry 1990;53:830-33. 